\title{
Inverse association of calcium intake with abdominal adiposity and C-reactive protein in Brazilian children
}

\author{
Lara Gomes Suhett*, Brenda Kelly Souza Silveira, Mariana De Santis Filgueiras, \\ Maria do Carmo Gouveia Peluzio, Helen Hermana Miranda Hermsdorff and \\ Juliana Farias de Novaes \\ Department of Nutrition and Health, Universidade Federal de Viçosa (UFV), Av. P.H. Rolfs s/n, Campus \\ Universitário, CEP 36570-000, Viçosa, MG, Brazil
}

Submitted 15 August 2017: Final revision received 1 November 2017: Accepted 16 January 2018: First published online 6 March 2018

\begin{abstract}
Objective: To evaluate $\mathrm{Ca}$ intake and its association with cardiometabolic risk factors during childhood.

Design: A cross-sectional study with a representative sample. Food consumption was assessed through three $24 \mathrm{~h}$ dietary recalls. Anthropometry, body composition and biochemical measurements were also conducted.

Setting: Viçosa, Minas Gerais, Brazil.

Subjects: Children between 8 and 9 years old ( $n$ 350) enrolled in public and private schools in the urban area of the municipality of Viçosa.

Results: Almost all children had inadequate intake of Ca (97.4\%), especially those with low income, non-white and who studied in public schools. Foods that contributed most to Ca intake were 'milk' and 'cheeses and yoghurts' $\left(R^{2}=0.66\right.$ and $0 \cdot 13$, respectively), and intake of 'milk' was correlated with 'chocolate milk powder' intake $(r=0.538, P<0 \cdot 01)$. Children with lower Ca intake had a higher prevalence of increased C-reactive protein (prevalence ratio $=2.93 ; 95 \%$ CI $1 \cdot 21$, 7.07), increased waist circumference (prevalence ratio $=2 \cdot 86 ; 95 \%$ CI $1 \cdot 01,8 \cdot 13$ ) and a lower prevalence of high LDL cholesterol (prevalence ratio $=0 \cdot 64 ; 95 \% \mathrm{CI}$ 0.41, 0.99).

Conclusions: Lower $\mathrm{Ca}$ intake was associated with excess abdominal adiposity and subclinical inflammation in Brazilian children. Monitoring of adequate Ca intake is important, especially in poorer communities.
\end{abstract}

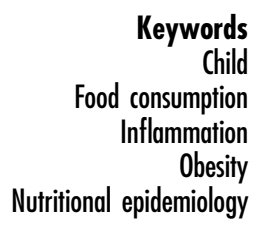

The number of children with cardiometabolic risk factors, such as excess abdominal adiposity, insulin resistance, dyslipidaemia and subclinical inflammation, has been increasing in many countries worldwide ${ }^{(1,2)}$. These metabolic alterations favour the development and progression of chronic non-communicable diseases during childhood $^{(3)}$ and, consequently, the reduction of life quality and expectancy ${ }^{(4)}$.

Studies with adults have identified low $\mathrm{Ca}$ intake to be inversely associated with systemic inflammation ${ }^{(5)}$, adiposity ${ }^{(6)}$ and risk of developing diabetes ${ }^{(7,8)}$ and hypertension ${ }^{(9)}$, as well as an increase in mortality rate ${ }^{(10)}$.

In children, adequate $\mathrm{Ca}$ intake has been associated with better blood pressure ${ }^{(11,12)}$ and lower values of body fat and $\mathrm{BMI}^{(13-15)}$; however, these results are still controversial $^{(16,17)}$. To date, no studies have been found evaluating the relationship between $\mathrm{Ca}$ intake and inflammatory markers in children.
Since there is a high prevalence of inadequate Ca intake among children ${ }^{(18-20)}$ and an adequate intake of this mineral may be related to better lipid profile, reduced inflammation and lower adiposity, the aim of the present study was to evaluate $\mathrm{Ca}$ intake and its association with cardiometabolic risk factors during childhood.

\section{Methodology}

\section{Participants}

The present study was a cross-sectional, populationbased study carried out with children between the ages of 8 and 9 years who were included in the Survey of Health Assessment of Schoolchildren (Pesquisa de Avaliação da Saúde do Escolar, PASE) and enrolled in one of the public or private schools in the city's urban area of Viçosa, Minas Gerais, Brazil. 
In 2015, this city had seventeen public schools and seven private schools in the urban area, with 1464 children aged 8-9 years enrolled. During sample size calculation, we considered the prevalence as $50 \%$ with multiple outcomes for cardiometabolic risk factors in this population, with a $95 \%$ confidence level, a tolerable error of 5\%, $10 \%$ for losses and $10 \%$ for confounding factors, adding up to a sample of 366 children. However, 378 schoolchildren enrolled in the third and fourth year of primary school were selected by stratified random sampling.

The sample from each school was proportional to the total number of enrolled students by age and sex. Students were selected randomly until the required number of each was completed. All urban schools of the city attended by children of this age range were evaluated ( $n$ 24). After the draw, the parents or guardians were invited to participate in the study through a telephone call. We explained all the objectives and methodology to them and the first meeting was scheduled. At this point, each step of the study had been clarified to the parents or guardians, and those who agreed to participate signed a written informed consent.

Children using Ca supplementation were not included, nor were those taking medications or with health conditions that modified the nutritional status, body composition, lipid profile, blood pressure or glucose metabolism of the child. Children who had physical, cognitive or multiple disabilities, and those whose legal guardian could not be contacted after three attempts, were also not included in the research. All children with C-reactive protein (CRP) $\geq 10 \mathrm{mg} / \mathrm{l}$ ( $n$ 28) were excluded since concentrations of this protein above this value are associated with infections and more serious inflammatory conditions, not subclinical inflammation. Thus, the final sample for the present study consisted of 350 children.

The study was conducted according to the guidelines laid down in the Declaration of Helsinki and all procedures involving human subjects were approved by the Ethics Committee on Human Research of the Federal University of Viçosa (case number 663.171/2014).

\section{Demographic data}

Sociodemographic data, such as sex, age, ethnicity, type of school (public or private), area of residence (urban or rural) and family per capita income, were collected by the researchers through a semi-structured questionnaire. Prior to beginning the research, a pilot study had been performed with $10 \%$ of the sample ( $n$ 37) in order to adjust the questionnaire as well as other measures evaluated in the research. Pilot children were not included in the final sample of the present study.

\section{Food consumption}

To estimate food consumption, three $24 \mathrm{~h}$ dietary recalls were applied on non-consecutive days, including one day of the weekend, and filled in according to information provided by the mother/guardian and the child. To increase data reliability, interviewers went through a specific training and during the interviews participants were shown standard utensils and photographic albums with food preparation and pictures distinguishing different portions ${ }^{(21)}$. Later, the measures done at each individual's house were transformed into grams or millilitres to analyse intakes of energy (in kilocalories) and $\mathrm{Ca}$ (in milligrams).

We estimated nutrient intakes from the $24 \mathrm{~h}$ dietary recall using Diet Pro ${ }^{\circledR} 5$ i software version 5.8. For this, the Brazilian Food Composition Table ${ }^{(22)}$ and the US Department of Agriculture's Food Composition Database ${ }^{(23)}$ were used.

To evaluate the adequacy of Ca intake, we considered the Estimated Average Requirement according to sex and life stage proposed by the Institute of Medicine ${ }^{(24)}$.

\section{Anthropometry and body composition}

Child weight was measured using an electronic digital scale with a capacity of $150 \mathrm{~kg}$ and sensitivity of $50 \mathrm{~g}$ (Tanita ${ }^{\circledR}$ model Ironman BC 553; Tanita Corporation of America, Inc., Arlington Heights, IL, USA), while child height was measured using a vertical stadiometer divided into centimetres and subdivided into millimetres (Alturexata $^{\circledR}$, Belo Horizonte, MG, Brazil) according to the norms of Jelliffe ${ }^{(25)}$. BMI was calculated based on weight and height. To classify children according to their nutritional status, BMI-for-age cut-off points by $Z$-score were calculated using the WHO Anthro Plus software ${ }^{(26)}$ and classified according to the $\mathrm{WHO}^{(27)}$. Children were considered to have excess weight when they were classified as overweight or obese by BMI.

Waist circumference was measured using an inelastic measuring tape divided into centimetres and subdivided into millimetres, with measurements taken at the midpoint between the iliac crest and the last rib $^{(28)}$. The 90th percentile of the sample was adopted to classify increased waist circumference due to the absence of cut-off points established for this age group. Waist-to-height ratio (WHtR) was calculated as the ratio of waist circumference to height. Cut-off point for WHtR of $\geq 0.5$ was considered as risk of development of cardiometabolic diseases ${ }^{(29)}$.

Body composition of the child was estimated by the dual-energy X-ray absorptiometry method (Lunar Prodigy Advance; GE Medical Systems Lunar, Milwaukee, WI, USA) and was classified according to cut-off points proposed by Lohman ${ }^{(30)}$

\section{Biochemical variables}

Blood collection was performed by a qualified professional after $12 \mathrm{~h}$ of fasting through a venepuncture procedure with disposable material. Samples were collected in a vacuum tube and centrifuged for $15 \mathrm{~min}$ at $3500 \mathrm{rpm}$; then the serum samples were separated into $1.5 \mathrm{ml}$ Eppendorf tubes and stored in an ultra-freezer at $-80^{\circ} \mathrm{C}$. 
Serum concentrations of total cholesterol (mg/dl), HDL cholesterol (HDL-C; mg/dl), LDL cholesterol (LDL-C; mg/dl), TAG $(\mathrm{mg} / \mathrm{dl})$ and insulin $(\mu \mathrm{U} / \mathrm{ml})$ were determined using BioSystems model 200 Mindray $^{\circledR}$ equipment (Nanchan, China) as recommended by the manufacturer of the Bioclin $^{\circledR}$ kits (Belo Horizonte, MG, Brazil).

Serum insulin was analysed through chemiluminescence immunoassay using the Elecsys Insulin ${ }^{\circledR}$ test (Roche Diagnostics, Indianapolis, IN, USA) with a detection limit of $0 \cdot 200-1000 \mu \mathrm{U} / \mathrm{ml}$. Insulin resistance was estimated by the homeostasis model assessment of insulin resistance (HOMA-IR) $^{(31)}$.

Levels of HDL-C $<45 \mathrm{mg} / \mathrm{dl}$, LDL-C $\geq 100 \mathrm{mg} / \mathrm{dl}$, TAG $\geq 100 \mathrm{mg} / \mathrm{dl}$, glucose $\geq 100 \mathrm{mg} / \mathrm{dl}$ and fasting insulin $>15 \mu \mathrm{U} / \mathrm{ml}$ were considered inadequate ${ }^{(32,33)}$. The 90th percentile of the sample was used to classify increases in high-sensitivity CRP and HOMA-IR assays due to the absence of cut-off points established for this age group.

\section{Statistical analysis}

The analysis was carried out using the statistical software packages IBM SPSS Statistics ${ }^{\circledR}$ version 24 and Stata version 13. The Kolmogorov-Smirnov test was used to evaluate the normality of the variables. Adjustment was made for intra-individual variability ${ }^{(34)}$ and for energy by the residual method ${ }^{(35)}$.

We divided the sample according to the 75 th percentile of $\mathrm{Ca}$ intake and used the Pearson $\chi^{2}$ test to verify associations between the variables. ANOVA was used for multiple comparisons in tertiles of $\mathrm{Ca}$ intake, with application of the post hoc Tukey test to identify the differences between the groups.

The multiple stepwise regression test was performed to verify which major food items contributed to the variability in $\mathrm{Ca}$ intake of the children.

Bivariate analysis was performed based on Poisson regression models with robust variance. Cardiometabolic risk factors were considered dependent variables with daily $\mathrm{Ca}$ intake as the explanatory variable. Predictive variables that obtained a $P$ value of $<0.20$ were inserted by the backward method in the multivariate Poisson regression model with robust variance. Variables with a lower level of significance $(P \geq 0.05)$ were taken one by one from the model. The models were still adjusted for potential confounding factors. The Hosmer-Lemeshow test was used to verify the adjustment of the final model. Prevalence ratio (PR) with 95\% CI was used as an effect measure. During all analyses, a significance level of $5 \%$ was adopted.

\section{Results}

Among the participating children ( $n$ 350), 52.6\% were female and $51.4 \%$ were 9 years old. The children with the lowest $\mathrm{Ca}$ intake were 9 years old, non-white, public-school students, with low HDL-C and high LDL-C $(P<0 \cdot 05$; Table 1$)$.

After adjusting the results for intra-individual variability, there was a high prevalence of inadequate $\mathrm{Ca}$ intake (97.4\%). In addition, the most consumed sources of $\mathrm{Ca}$ were 'milk' and 'cheeses and yoghurts' $\left(R^{2}=0.66\right.$ and $0 \cdot 13$, respectively). There was a moderate correlation between milk consumption and chocolate milk powder $(r=0.538$, $P<0 \cdot 01)$. Food items listed in Table 2 explained 66-91\% of the total variability of $\mathrm{Ca}$ intake.

Individuals with $\mathrm{Ca}$ intake in the first tertile had lower mean per capita income $(P<0 \cdot 001$; Table 3$)$ and higher serum level of CRP $(P=0 \cdot 012$; Fig. 1) when compared with the second and third tertiles.

In the adjusted regression models, children with $\mathrm{Ca}$ consumption in the first tertile $(0-341.98 \mathrm{mg})$ presented higher prevalence of increased waist circumference $(\mathrm{PR}=2 \cdot 86 ; 95 \%$ CI $1.01,8.13 ; P=0.048)$ and increased CRP (PR $=2.93 ; 95 \%$ CI 1.21, 7.07; $P=0.017)$, as well as a lower prevalence of increased LDL-C (PR $=0.64 ; 95 \% \mathrm{CI}$ $0.41,0.99 ; P=0.047)$, compared with children in the third tertile of Ca consumption ( $\geq 485.82 \mathrm{mg}$; Table 4 ).

\section{Discussion}

Children with lower $\mathrm{Ca}$ intake had higher prevalence of increased CRP, increased waist circumference, as well as a lower prevalence of elevated LDL-C.

Higher serum concentration of CRP in children with lower Ca intake may be related to bioactive compounds present in dairy foods, such as $\mathrm{Ca}$, phospholipids, proteins and peptides, which may decrease the inflammatory process in adipose tissue by decreasing the serum concentration of $\mathrm{CRP}^{(36-38)}$. In research done with adults, Labonté et $a l^{(39)}$ observed an improvement in concentration of inflammatory markers, including reduction of serum CRP, due to an increased consumption of Ca-containing food sources. On the other hand, other studies with adolescents and adults identified a null effect of dairy intake on the CRP concentration $^{(5,40-43)}$. Therefore, since these findings are controversial in adults and no studies have been found with children, the present study highlights the need for longitudinal investigations with child populations to elucidate possible mechanisms involved in the relationship between $\mathrm{Ca}$ intake and the presence of subclinical inflammation.

The inverse association between $\mathrm{Ca}$ intake and abdominal adiposity identified in the current study corroborates other investigations carried out with 10-12-year-old boys ${ }^{(44)}$, 12-19-year-old girls ${ }^{(6)}$ and 7-18-year-old obese children and adolescents $^{(45)}$. Major et $a l^{(46)}$ identified a possible mechanism to explain the relationship between low Ca intake and abdominal obesity. Adequate $\mathrm{Ca}$ intake can reduce the concentration of calcitriol. Therefore, autocrine activation of cortisol synthesis would decrease, leading to less fat accumulation ${ }^{(47,48)}$. This occurs because calcitriol 
Table 1 Sociodemographic, anthropometric and biochemical variables according to calcium intake among urban schoolchildren aged 8-9 years ( $n$ 350), Viçosa, Minas Gerais, Brazil, 2015

\begin{tabular}{|c|c|c|c|c|c|c|c|}
\hline \multirow[b]{3}{*}{ Variable } & & & \multicolumn{4}{|c|}{ Ca intake (mg) } & \multirow[b]{3}{*}{$P$ value } \\
\hline & \multicolumn{2}{|c|}{ Total } & \multicolumn{2}{|c|}{$<\mathrm{P} 75$} & \multicolumn{2}{|c|}{$\geq \mathrm{P} 75$} & \\
\hline & $n$ & $\%$ & $n$ & $\%$ & $n$ & $\%$ & \\
\hline Sex & & & & & & & 0.667 \\
\hline Male & 166 & 47.4 & 123 & $74 \cdot 1$ & 43 & 25.9 & \\
\hline Female & 184 & $52 \cdot 6$ & 140 & $76 \cdot 1$ & 44 & 23.9 & \\
\hline Age (years) & & & & & & & $0.001^{*}$ \\
\hline 8 & 170 & 48.6 & 114 & $67 \cdot 1$ & 56 & 32.9 & \\
\hline 9 & 180 & $51 \cdot 4$ & 149 & $82 \cdot 8$ & 31 & $17 \cdot 2$ & \\
\hline Ethnicity & & & & & & & $0.001^{*}$ \\
\hline White & 114 & $32 \cdot 6$ & 73 & 64.0 & 41 & $36 \cdot 0$ & \\
\hline Non-white & 236 & $67 \cdot 4$ & 190 & 80.5 & 46 & 19.5 & \\
\hline Type of school & & & & & & & $0.016^{*}$ \\
\hline Public & 245 & $70 \cdot 0$ & 193 & $78 \cdot 8$ & 52 & $21 \cdot 2$ & \\
\hline Private & 105 & $30 \cdot 0$ & 70 & $66 \cdot 7$ & 35 & $33 \cdot 3$ & \\
\hline Residence area & & & & & & & 0.307 \\
\hline Urban & 333 & 95.1 & 252 & $75 \cdot 7$ & 81 & $24 \cdot 3$ & \\
\hline Rural & 17 & 4.9 & 11 & 64.7 & 6 & $35 \cdot 3$ & \\
\hline Maternal education (years) & & & & & & & 0.094 \\
\hline$<8$ & 85 & $24 \cdot 3$ & 70 & 82.4 & 15 & $17 \cdot 6$ & \\
\hline$\geq 8$ & 263 & $75 \cdot 1$ & 193 & 73.4 & 70 & $26 \cdot 6$ & \\
\hline BMI $\left(\mathrm{kg} / \mathrm{m}^{2}\right)$ & & & & & & & 0.626 \\
\hline Adequate & 238 & 68.0 & 177 & 74.4 & 61 & $25 \cdot 6$ & \\
\hline Excess of weight & 112 & $32 \cdot 0$ & 86 & $76 \cdot 8$ & 26 & $23 \cdot 2$ & \\
\hline Waist circumference $(\mathrm{cm})$ & & & & & & & 0.611 \\
\hline Adequate $(<\mathrm{P} 90)$ & 317 & $90 \cdot 6$ & 237 & 74.8 & 80 & $25 \cdot 2$ & \\
\hline Increased $(\geq \mathrm{P} 90)$ & 33 & 9.4 & 26 & $78 \cdot 8$ & 7 & $21 \cdot 2$ & \\
\hline WHtR & & & & & & & 0.507 \\
\hline Adequate & 292 & $83 \cdot 4$ & 217 & 82.5 & 75 & $86 \cdot 2$ & \\
\hline Increased & 58 & $16 \cdot 6$ & 46 & $17 \cdot 5$ & 12 & $13 \cdot 8$ & \\
\hline BF (\%) & & & & & & & 0.215 \\
\hline Adequate & 181 & 51.7 & 131 & 72.4 & 50 & $27 \cdot 6$ & \\
\hline Excess of adiposity & 169 & $48 \cdot 3$ & 132 & $78 \cdot 1$ & 37 & 21.9 & \\
\hline $\mathrm{TC}(\mathrm{mg} / \mathrm{dl})$ & & & & & & & 0.145 \\
\hline Adequate & 292 & 83.4 & 132 & $78 \cdot 6$ & 36 & 21.4 & \\
\hline Increased & 58 & $16 \cdot 6$ & 130 & 71.8 & 51 & $28 \cdot 2$ & \\
\hline HDL-C (mg/dl) & & & & & & & $0.041^{*}$ \\
\hline Adequate & 251 & $71 \cdot 7$ & 181 & $72 \cdot 1$ & 70 & 27.9 & \\
\hline Low & 98 & $28 \cdot 0$ & 81 & $82 \cdot 7$ & 17 & $17 \cdot 3$ & \\
\hline LDL-C (mg/dl) & & & & & & & $0.011^{*}$ \\
\hline Adequate & 256 & 73.1 & 202 & 78.9 & 54 & $21 \cdot 1$ & \\
\hline Increased & 93 & $26 \cdot 6$ & 61 & $65 \cdot 6$ & 32 & 34.4 & \\
\hline TAG (mg/dl) & & & & & & & 0.330 \\
\hline Adequate & 285 & $81 \cdot 4$ & 217 & $76 \cdot 1$ & 68 & 23.9 & \\
\hline Increased & 64 & $18 \cdot 3$ & 45 & $70 \cdot 3$ & 19 & $29 \cdot 7$ & \\
\hline CRP (mg/l) & & & & & & & 0.053 \\
\hline Adequate $(<\mathrm{P} 90)$ & 315 & $90 \cdot 0$ & 232 & $73 \cdot 7$ & 83 & $26 \cdot 3$ & \\
\hline Increased $(\geq P 90)$ & 35 & $10 \cdot 0$ & 31 & 88.6 & 4 & 11.4 & \\
\hline Glucose (mg/dl) & & & & & & & 0.637 \\
\hline Adequate & 343 & 98.0 & 257 & 79.4 & 86 & $25 \cdot 1$ & \\
\hline Increased & 6 & $1 \cdot 7$ & 5 & 83.3 & 1 & $16 \cdot 7$ & \\
\hline HOMA-IR & & & & & & & 0.638 \\
\hline Adequate $(<\mathrm{P} 90)$ & 341 & $97 \cdot 4$ & 256 & $75 \cdot 1$ & 85 & 29.4 & \\
\hline Increased $(\geq P 90)$ & 6 & 1.7 & 4 & $66 \cdot 7$ & 2 & $33 \cdot 3$ & \\
\hline
\end{tabular}

P75, 75th percentile; P90, 90th percentile; WHtR, waist-to-height ratio; BF (\%), body fat percentage; TC, total cholesterol; HDL-C, HDL cholesterol; LDL-C, LDL cholesterol; CRP, C-reactive protein; HOMA-IR, homeostasis model assessment of insulin resistance. ${ }^{\star} P<0.05$ (Pearson's $\chi^{2}$ test).

stimulates the expression of 11- $\beta$-hydroxysteroid dehydrogenase-1, which helps in the conversion of cortisone into cortisol, a substance that acts in the accumulation of fat, mainly in the abdominal region ${ }^{(49)}$. Another accepted mechanism is the increase in the oxidative capacity of adipose tissue when there is an adequate intake of Ca. Higher intake of this mineral would induce intracellular
Ca content to decrease in adipose tissue, promoting fat oxidation rather than its deposition ${ }^{(44)}$.

Children with $\mathrm{Ca}$ consumption in the first tertile had a lower prevalence of increased LDL-C. We believe that sugar-rich chocolate powder addition to milk may have contributed to this finding since, in the present study, milk accounted for $66 \%$ of $\mathrm{Ca}$ intake. Furthermore, all children 
who reported to consume milk ( $n$ 213) were recorded to do so with chocolate milk powder, which corresponds to $60 \cdot 8 \%$ of the total sample ( $n$ 350). Frequent intake of powdered chocolate by children has been described (19-6-49\%) ${ }^{(50,51)}$ and usually associated with milk ${ }^{(52,53)}$. Ingestion of sugar contributes to an increase in adiposity ${ }^{(54,55)}$ and LDL-C ${ }^{(56,57)}$, since excessive sugar intake is involved in the synthesis of free radicals, such as reactive oxygen species, cytokines and molecular adhesion molecules. These components lead to the formation of oxidized LDL-C, which stimulates the migration of macrophages to form foam cells, resulting in the progression of atherosclerosis ${ }^{(58)}$.

Dairy foods may be high in saturated fats and an elevated consumption of this nutrient is associated with worsening markers of cardiovascular risk ${ }^{(59,60)}$. However, some studies did not find a relationship of fat intake from dairy products with worsening of the lipid profile, inflammation and obesity ${ }^{(61-64)}$. This may be because $\mathrm{Ca}$ forms insoluble soaps with fatty acids, preventing them from being absorbed since Ca causes fatty acids to be bounded to bile salts, preventing their resorption in the intestine $^{(65)}$. Thus, greater fat excretion occurs when there is higher $\mathrm{Ca}$ content in the diet ${ }^{(66,67)}$.

Table 2 Main food items consumed that contributed to calcium intake by urban schoolchildren aged 8-9 years ( $n$ 350), Viçosa, Minas Gerais, Brazil, 2015

\begin{tabular}{lcc}
\hline Food group & $R^{2}$ & Accumulated $R^{2}$ \\
\hline Milk & 0.66 & 0.66 \\
Cheeses and yoghurts & 0.13 & 0.79 \\
Sweets and desserts $\dagger$ & 0.06 & 0.85 \\
Fortified cerealsł & 0.04 & 0.89 \\
Fishes & 0.01 & 0.90 \\
Leguminous & 0.01 & 0.91 \\
\hline
\end{tabular}

†lce cream, milkshake, chocolate powder, industrialized chocolate milk, chocolate, sweets in general.

‡Mucilon, breakfast cereal, milk flour, breads, cookies and cakes.
Another result to be highlighted is the inadequate intake of $\mathrm{Ca}$ in $97.4 \%$ of the sample. In fact, $\mathrm{Ca}$ is one of the micronutrients with the highest rate of inadequate consumption worldwide ${ }^{(68)}$. In the literature, most studies with children and adolescents have identified low $\mathrm{Ca}$ intake (88.6-97.6\%), corroborating the results of the current study ${ }^{(12,69,70)}$. Low Ca intake is worrying because this mineral is important for child growth and may be involved with early development of cardiometabolic diseases $^{(38,46,71)}$. However, we do not know if the high prevalence of inadequate Ca intake among children in our study could affect its relationship to the cardiometabolic risk factors, since few children presented adequate $\mathrm{Ca}$ intake ( $n 9 \cdot 1,2 \cdot 6 \%$ ). Therefore, studies conducted with a larger sample size are of scientific interest.

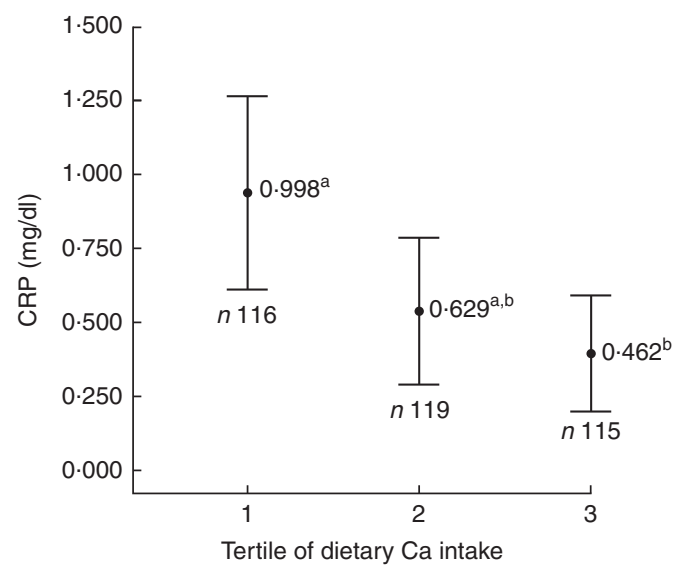

Fig. 1 Mean serum concentration of C-reactive protein (CRP), with $95 \% \mathrm{Cl}$ represented by vertical bars, according to tertile of calcium intake among urban schoolchildren aged 8-9 years (n 350), Viçosa, Minas Gerais, Brazil, 2015. a,b Mean values with unlike superscript letters were significantly different: $P=0.012^{*} .{ }^{*} P<0.05$ (ANOVA with post hoc Tukey test)

Table 3 Sociodemographic, anthropometric and biochemical variables according to tertile of calcium intake among urban schoolchildren aged 8-9 years ( $n$ 350), Viçosa, Minas Gerais, Brazil, 2015

\begin{tabular}{|c|c|c|c|c|c|c|c|}
\hline \multirow[b]{3}{*}{ Variables } & \multicolumn{6}{|c|}{ Ca intake (mg) } & \multirow[b]{3}{*}{$P$ value } \\
\hline & \multicolumn{2}{|c|}{ 1st tertile ( $n$ 116) } & \multicolumn{2}{|c|}{ 2nd tertile ( $n$ 119) } & \multicolumn{2}{|c|}{ 3rd tertile $(n 115)$} & \\
\hline & Mean & SD & Mean & SD & Mean & SD & \\
\hline Income per capita (reais) & $506 \cdot 08^{a}$ & $440 \cdot 20$ & $734.51^{b}$ & $721 \cdot 19$ & $951.93^{b}$ & 825.73 & $<0.001^{*}$ \\
\hline BMI $\left(\mathrm{kg} / \mathrm{m}^{2}\right)$ & $17 \cdot 80$ & 3.87 & 17.58 & 3.33 & 16.95 & 2.97 & 0.456 \\
\hline Waist circumference $(\mathrm{cm})$ & $61 \cdot 38$ & $10 \cdot 45$ & $60 \cdot 97$ & $9 \cdot 21$ & $58 \cdot 72$ & $8 \cdot 14$ & 0.269 \\
\hline WHtR & 0.45 & 0.06 & 0.44 & 0.06 & 0.43 & 0.05 & 0.213 \\
\hline $\mathrm{BF}(\%)$ & 24.99 & $11 \cdot 16$ & $23 \cdot 71$ & 9.69 & 23.35 & 9.57 & 0.807 \\
\hline $\mathrm{TC}(\mathrm{mg} / \mathrm{dl})$ & $150 \cdot 64$ & $22 \cdot 38$ & $152 \cdot 14$ & $27 \cdot 07$ & $156 \cdot 80$ & 29.05 & 0.151 \\
\hline HDL-C (mg/dl) & 49.19 & 9.60 & $50 \cdot 20$ & 10.93 & 52.43 & 9.93 & 0.182 \\
\hline LDL-C (mg/dl) & 84.79 & $20 \cdot 60$ & $85 \cdot 28$ & $20 \cdot 76$ & 90.50 & $24 \cdot 26$ & 0.097 \\
\hline TAG (mg/dl) & 79.56 & $40 \cdot 66$ & 76.99 & $38 \cdot 90$ & $82 \cdot 83$ & $35 \cdot 78$ & 0.536 \\
\hline Glucose $(\mathrm{mg} / \mathrm{dl})$ & 84.72 & 8.87 & 84.62 & 7.37 & 85.49 & 7.00 & 0.602 \\
\hline HOMA-IR & $1 \cdot 19$ & 0.72 & $1 \cdot 19$ & 1.02 & $1 \cdot 11$ & 0.66 & 0.490 \\
\hline
\end{tabular}

WHtR, waist-to-height ratio; BF (\%), body fat percentage; TC, total cholesterol; HDL-C, HDL cholesterol; LDL-C, LDL cholesterol; HOMA-IR. homeostasis model assessment of insulin resistance.

${ }^{a, b}$ Mean values within a row with unlike superscript letters were significantly different.

${ }^{\star} P<0.05$ (ANOVA with post hoc Tukey test). 
Table 4 Crude and adjusted prevalence ratios (PR) of the association between calcium consumption tertile and cardiometabolic markers among urban schoolchildren aged 8-9 years ( $n$ 350), Viçosa, Minas Gerais, Brazil, 2015

\begin{tabular}{|c|c|c|c|c|c|c|}
\hline \multirow[b]{3}{*}{ Cardiometabolic marker } & \multicolumn{6}{|c|}{ Ca intake $(\mathrm{mg})$} \\
\hline & \multicolumn{2}{|c|}{ 1st tertile } & \multicolumn{2}{|c|}{ 2nd tertile } & \multicolumn{2}{|c|}{ 3rd tertile } \\
\hline & PR & $95 \% \mathrm{Cl}$ & PR & $95 \% \mathrm{Cl}$ & PR & $95 \% \mathrm{Cl}$ \\
\hline \multicolumn{7}{|c|}{ Waist circumference ( $\geq$ P90) } \\
\hline Crude & 1.73 & $0.76,3.98$ & 1.33 & $0.55,3.19$ & & ence \\
\hline$P$ value & \multicolumn{2}{|c|}{0.194} & \multicolumn{2}{|c|}{0.524} & & \\
\hline Adjusted $\dagger$ & $2 \cdot 86$ & $1 \cdot 01,8 \cdot 13$ & 1.79 & $0.63,5.08$ & \multirow{2}{*}{\multicolumn{2}{|c|}{ Reference }} \\
\hline$P$ value & \multicolumn{2}{|c|}{$0.048^{*}$} & \multicolumn{2}{|c|}{0.270} & & \\
\hline \multicolumn{7}{|l|}{ LDL-C ( $\geq 100 \mathrm{mg} / \mathrm{dl})$} \\
\hline Crude & 0.64 & $0.41,0.99$ & 0.75 & $0.50,1.13$ & & ence \\
\hline$P$ value & \multicolumn{2}{|c|}{$0.049^{*}$} & \multicolumn{2}{|c|}{0.176} & \multirow{3}{*}{\multicolumn{2}{|c|}{ Reference }} \\
\hline Adjusted $\ddagger$ & 0.64 & $0.41,0.99$ & 0.75 & $0.50,1.13$ & & \\
\hline$P$ value & \multicolumn{2}{|c|}{$0.047^{*}$} & \multicolumn{2}{|c|}{0.174} & & \\
\hline \multicolumn{7}{|l|}{ CRP ( $\geq$ P90) } \\
\hline Crude & $2 \cdot 64$ & $1.07,6.52$ & 1.61 & $0.60,4 \cdot 29$ & & ence \\
\hline$P$ value & \multicolumn{2}{|c|}{$0.035^{\star}$} & \multicolumn{2}{|c|}{0.341} & \multirow{3}{*}{\multicolumn{2}{|c|}{ Reference }} \\
\hline Adjusted $\ddagger$ & 2.93 & $1 \cdot 21,7 \cdot 07$ & 1.69 & $0.65,4.42$ & & \\
\hline$P$ value & \multicolumn{2}{|c|}{$0.017^{*}$} & \multicolumn{2}{|c|}{0.277} & & \\
\hline
\end{tabular}

In the present study, milk was the main contributor to Ca intake (66\%), followed by cheeses and yoghurts (13\%; Table 3). Milk has a lower cost compared with other dairy products, which may explain its higher consumption ${ }^{(72)}$. On the other hand, dark green leaves did not contribute to explain the variability in $\mathrm{Ca}$ intake, since many children (83\%) consumed less than one portion of these foods daily, well below the daily recommendation of three portions $^{(73)}$.

Non-white children with lower socio-economic status (lower income per capita and students from public schools) had lower $\mathrm{Ca}$ intakes. In addition, $84.3 \%$ of non-white study children had an income of up to one minimum wage per capita. Epidemiological studies with child and adolescent populations have also shown that individuals with lower income and those studying in public schools present lower intakes of $\mathrm{Ca}^{(70,72)}$. Another study evaluating dairy intake according to income, using data from the Household Budget Survey (2002-2003), identified a positive association between $\mathrm{Ca}$ intake and income in Brazilian families ${ }^{(74)}$. In this sense, acquisition of dairy products, which are the main sources of $\mathrm{Ca}$, may not be affordable to the budget of low-income families. Thus, they opt for other lower-cost foods.

The current study has some limitations. Because of the cross-sectional design, it is not possible to establish a temporal relationship between $\mathrm{Ca}$ intake and cardiometabolic risk factors since the direction of causality is unknown; that is, if the lower consumption of Ca causes cardiometabolic changes or vice versa. In addition, the instrument used to estimate dietary intake ( $24 \mathrm{~h}$ recall) may show poor estimates because it depends on the memory of the children and their legal guardian. However, some good points should be highlighted. We used strategies to reduce memory bias and improve portion estimation, such as interviewer training and the use of photo albums and standard tools. Adjustment of Ca intake was also made to account for intra-individual variability and total energy intake. In addition, the present study is one of the few that have evaluated the relationship of $\mathrm{Ca}$ intake with cardiometabolic risk factors and inflammatory markers in the child population; and it is the first Brazilian study within this age group to date.

\section{Conclusion}

In conclusion, lower intake of $\mathrm{Ca}$ in Brazilian children was found to be associated with excess abdominal adiposity and subclinical inflammation. Prevalence of inadequate $\mathrm{Ca}$ intake was high, with the lowest intake being observed in low-income, non-white children and those attending public schools. Furthermore, effective performance of health professionals in monitoring adequate $\mathrm{Ca}$ intake is important, especially in poorer communities. Lastly, longitudinal studies are needed to better elucidate the causal direction between low $\mathrm{Ca}$ intake and cardiometabolic risk factors in the child population, especially in developing countries such as Brazil.

\section{Acknowledgements}

Acknowledgements: The authors thank all children who participated in this work and their parents/guardians; 
BioClin $^{\circledR}$ (Belo Horizonte, MG, Brazil) for their support in the biochemical analyses and Diet Pro ${ }^{\circledR}$ software for the license granted; and the Coordenação de Aperfeiçoamento de Pessoal de Nível Superior (CAPES) and the Fundação de Amparo à Pesquisa do Estado de Minas Gerais (FAPEMIG) for the scholarships granted to L.G.S., B.K.S.S. and M.S.F. Financial support: This work was supported by the Conselho Nacional de Desenvolvimento Científico e Tecnológico (CNPq) (grant number 407547/ 2012-6). H.H.M.H. and M.C.G.P. have a fellowship in Research Productivity from CNPq. The CNPq had no role in the design, analysis or writing of this article. Conflict of interest: The authors declare no conflict of interest. Authorship: L.G.S. assisted the conception and design of this work, analysis and interpretation of the data, conducted the literature search, as well as wrote the manuscript. B.K.S.S. contributed to analysis and interpretation of the data, conducted the literature search, as well as wrote the manuscript. M.S.F. assisted in data collection, analysis and interpretation of the data, and revised and approved the final version to be published. M.C.G.P. revised and approved the final version to be published. H.H.M.H. assisted in the interpretation of results and approved the final version to be published. J.F.N. designed the study including the data collection and coordinated, supervised and approved the final version to be published. Ethics of buman subject participation: This study was conducted according to the guidelines laid down in the Declaration of Helsinki and all the procedures involving human subjects were approved by the Ethics Committee on Human Research of the Federal University of Viçosa (case number 663.171/2014). Moreover, this project was presented to the Municipal Department of Education, the Regional Superintendent of Education and principals of schools. All participants, as well as their responsible parents/guardians, were informed about the objectives of the research and written informed consent was obtained from all children's parents.

\section{References}

1. Damsgaard CT, Dalskov S, Laursen RP et al. (2014) Provision of healthy school meals does not affect the metabolic syndrome score in 8-11-year-old children, but reduces cardiometabolic risk markers despite increasing waist circumference. Br J Nutr 112, 1826-1836.

2. Wang Y \& Lobstein T (2006) Worldwide trends in childhood overweight and obesity. Int J Pediatr Obes 1, 11-25.

3. Freedman DS, Khan LK, Serdula MK et al. (2005) The relation of childhood BMI to adult adiposity: the Bogalusa Heart Study. Pediatrics 115, 22-27.

4. Hulsegge G, Looman M, Smit HA et al. (2016) Lifestyle changes in young adulthood and middle age and risk of cardiovascular disease and all-cause mortality: the Doetinchem Cohort Study. J Am Heart Assoc 5, e002432.

5. Zemel MB \& Sun X (2008) Dietary calcium and dairy products modulate oxidative and inflammatory stress in mice and humans. J Nutr 138, 1047-1052.
6. Castro Burbano J, Fajardo Vanegas P, Robles Rodríguez J et al. (2016) Relationship between dietary calcium intake and adiposity in female adolescents. Endocrinol Nutr $\mathbf{6 3}$, 58-63.

7. Pittas AG, Lau J, Hu FB et al. (2007) The role of vitamin D and calcium in type 2 diabetes. A systematic review and meta-analysis. J Clin Endocrinol Metab 92, 2017-2029.

8. Martini LA, Catania AS \& Ferreira SRG (2010) Role of vitamins and minerals in prevention and management of type 2 diabetes mellitus. Nutr Rev 68, 341-354.

9. Wang L, Manson JE, Buring JE et al. (2008) Dietary intake of dairy products, calcium, and vitamin D and the risk of hypertension in middle-aged and older women. Hypertension 51, 1073-1079.

10. Asemi Z, Saneei P, Sabihi SS et al. (2015) Total, dietary, and supplemental calcium intake and mortality from all-causes, cardiovascular disease, and cancer: a meta-analysis of observational studies. Nutr Metab Cardiovasc Dis 25, 623-634.

11. Rangan AM, Flood VL, Denyer G et al. (2012) The effect of dairy consumption on blood pressure in mid-childhood: CAPS cohort study. Eur J Clin Nutr 66, 652-657.

12. Magalhães EI, Pessoa MC, Franceschini SD et al. (2017) Dietary calcium intake is inversely associated with blood pressure in Brazilian children. Int J Food Sci Nutr 68, 331-338.

13. Skinner JD, Bounds W, Carruth BR et al. (2003) Longitudinal calcium intake is negatively related to children's body fat indexes. J Am Diet Assoc 103, 1626-1631.

14. Keast DR, Gallant KMH, Albertson AM et al. (2015) Associations between yogurt, dairy, calcium, and vitamin D intake and obesity among US children aged 8-18 years: NHANES, 2005-2008. Nutrients 7, 1577-1593.

15. Dixon LB, Pellizzon MA, Jawad AF et al. (2005) Calcium and dairy intake and measures of obesity in hyperand normocholesterolemic children. Obes Res 13, $1727-1738$.

16. Weaver CM, Campbell WW, Teegarden D et al. (2011) Calcium, dairy products, and energy balance in overweight adolescents: a controlled trial. Am J Clin Nutr 94, 1163-1170.

17. Moreira P, Padez C, Mourão I et al. (2005) Dietary calcium and body mass index in Portuguese children. Eur J Clin Nutr 59, 861-867.

18. Oliveira CF, Silveira CR, Beghetto M et al. (2014) Assessment of calcium intake by adolescents. Rev Paul Pediatr 32, 216-220.

19. Tylavsky FA, Cowan PA, Terrell S et al. (2010) Calcium Intake and body composition in African-American children and adolescents at risk for overweight and obesity. Nutrients 2, 950-964.

20. Santos LC, Martini LA, Freitas SN et al. (2007) Calcium intake and anthropometric indicators in adolescents. Rev Nutr 20, 275-283.

21. Zabotto CB, Vianna RPT \& Gil MF (1996) Registro Fotográfico Para Inquéritos Dietéticos: Utensílios e Porções. Goiânia: Nepa-Unicamp; available at http://www.fcm. unicamp.br/fcm/sites/default/files/2016/page/manual_ fotografico.pdf

22. Núcleo de Estudos e Pesquisas em Alimentação, Universidade Estadual de Campinas (2011) Tabela Brasileira de Composição de Alimentos - TACO, $4^{\mathrm{a}}$ ed. rev. e ampl. Campinas: Nepa-Unicamp.

23. US Department of Agriculture, Agricultural Research Service (2016) USDA National Nutrient Database for Standard Reference (Release 28). http://www.fnic.nal.usda.gov/ food-composition/usda-nutrient-data-laboratory (accessed July 2017).

24. Institute of Medicine (2011) Dietary Reference Intakes for Calcium and Vitamin D. Washington, DC: The National Academies Press. 
25. Jellife DB \& World Health Organization (1968) Evaluación del Estado de Nutrición de la Comunidad. Geneva: WHO; available at http://www.apps.who.int/iris/handle/10665/41408

26. World Health Organization (2009) WHO AnthroPlus for Personal Computers Manual: Software for Assessing Growth of the World's Children and Adolescents. Geneva: WHO.

27. de Onis M, Onyango AW, Borghi E et al. (2007) Development of a WHO growth reference for school-aged children and adolescents. Bull World Health Organ 85, 660-667.

28. World Health Organization (2000) Obesity: Preventing and Managing the Global Epidemic. Report of a WHO Consultation. WHO Technical Report Series no. 894. Geneva: WHO.

29. Ashwell M \& Hsieh SD (2005) Six reasons why the waistto-height ratio is a rapid and effective global indicator for health risks of obesity and how its use could simplify the international public health message on obesity. Int J Food Sci Nutr 56, 303-307.

30. Lohman TG (1992) Advances in Body Composition Assessment: Current Issues in Exercise Science. Champaign, IL: Human Kinetics Publishers.

31. Matthews DR, Hosker JP, Rudenski AS et al. (1985) Homeostasis model assessment: insulin resistance and $\beta$-cell function from fasting plasma glucose and insulin concentrations in man. Diabetologia 28, 412-419.

32. Sociedade Brasileira de Cardiologia (2005) I diretriz de prevenção da aterosclerose na infância e na adolescência. Arq Bras Cardiol 85, 4-35.

33. American Dietetic Association (2006) Diagnosis and classification of diabetes mellitus. Position statement. Diabetes Care 29, Suppl. 1, 43S-48S

34. Fisberg RM, Marchioni DML \& Colucci ACA (2009) Avaliação do consumo alimentar e da ingestão de nutrientes na prática clínica. Arq Bras Endocrinol Metab 53, 617-624.

35. Willett W (2013) Nutritional Epidemiology, 3th ed. New York: Oxford University Press.

36. Zemel MB \& Sun X (2008) Dietary calcium and dairy products modulate oxidative and inflammatory stress in mice and humans. J Nutr 138, 1047-1052.

37. Beermann C \& Hartung J (2013) Physiological properties of milk ingredients released by fermentation. Food Funct $\mathbf{4}$, 185-199.

38. Astrup A (2014) Yogurt and dairy product consumption to prevent cardiometabolic diseases: epidemiologic and experimental studies. Am J Clin Nutr 99, 5 Suppl., 1235S-1242S.

39. Labonté MÈ, Couture P, Richard C et al. (2013) Impact of dairy products on biomarkers of inflammation: a systematic review of randomized controlled nutritional intervention studies in overweight and obese adults. Am J Clin Nutr 97, 706-717.

40. Ghayour-Mobarhan M, Sahebkar A, Vakili R, Safarian M et al. (2009) Investigation of the effect of high dairy diet on body mass index and body fat in overweight and obese children. Indian J Pediatr 76, 1145-1150.

41. Benatar JR, Sidhu K \& Stewart RAH (2013) Effects of high and low fat dairy food on cardio-metabolic risk factors: a meta-analysis of randomized studies. PLoS One 8, e76480.

42. Labonté MÈ, Cyr A, Abdullah MM et al. (2014) Dairy product consumption has no impact on biomarkers of inflammation among men and women with low-grade systemic inflammation. J Nutr 144, 1760-1767.

43. Schmid A, Petry N, Walther B et al. (2015) Inflammatory and metabolic responses to high-fat meals with and without dairy products in men. Br J Nutr 113, 1853-1861.

44. Chen Y, Liu Y, Xue H et al. (2016) Association between dietary calcium/dairy intakes and overweight/obesity. Wei Sheng Yan Jiu 5, 402-408.

45. Czerwonogrodzka A, Pyrzak B, Majcher A et al. (2008) Assessment of dietary calcium intake on metabolic syndrome frequency in obese children and adolescents. Pediatr Endocrinol Diabetes Metab 14, 231-235.

46. Major GC, Chaput JP, Ledoux M et al. (2008) Recent developments in calcium-related obesity research. Obes Rev 9, 428-445.

47. Da Cunha KA, Magalhães ELS, Loureiro IMR et al. (2015) Ingestão de cálcio, níveis séricos de vitamina $\mathrm{D}$ e obesidade infantil: existe associação? Rev Paul Pediatr 33, 222-229.

48. Zemel MB \& Miller SL (2004) Dietary calcium and dairy modulation of adiposity and obesity risk. Nutr Rev $\mathbf{6 2}$, 125-131.

49. Dougkas A, Reynolds CK, Givens ID et al. (2011) Associations between dairy consumption and body weight: a review of the evidence and underlying mechanisms. Nutr Res Rev 24, 75-95.

50. Aquino RC \& Philippi ST (2002) Association of children's consumption of processed foods and family income in the city of São Paulo, Brazil. Rev Saude Publica 36, 655-660.

51. Hinning PF \& Bergamaschi DP (2012) Itens alimentares no consumo alimentar de crianças de 7 a 10 anos. Rev Bras Epidemiol 15, 324-334.

52. Henry C, Whiting SJ, Finch SL et al. (2016) Impact of replacing regular chocolate milk with the reduced-sugar option on milk consumption in elementary schools in Saskatoon, Canada. Appl Physiol Nutr Metab 1, 511-515.

53. Araujo AM, Brandão AS, Araújo AM et al. (2017) Overweight and obesity in preschoolers: prevalence and relation to food consumption. Rev Assoc Med Bras (1992) 63, 124-133.

54. Frantsve-Hawley J, Bader JD, Welsh JA et al. (2017) A systematic review of the association between consumption of sugar-containing beverages and excess weight gain among children under age 12. J Public Health Dent 77, Suppl. 1, S43-S66.

55. Lee AK, Chowdhury R \& Welsh JA (2015) Sugars and adiposity: the long-term effects of consuming added and naturally occurring sugars in foods and in beverages. Obes Sci Pract 1, 41-49.

56. Murakami K \& Livingstone MB (2015) Variability in eating frequency in relation to adiposity measures and blood lipid profiles in British children and adolescents: findings from the National Diet and Nutrition Survey. Int J Obes (Lond) 39, 608-613.

57. Davis MM, Spurlock M, Ramsey K et al. (2017) Milk Options Observation (MOO): a mixed-methods study of chocolate milk removal on beverage consumption and student/staff behaviors in a rural elementary school. J Sch Nurs 33, 285-298.

58. Prasad K \& Dhar I (2014) Oxidative stress as a mechanism of added sugar-induced cardiovascular disease. Int J Angiol 23, 217-226.

59. Astrup A, Dyerberg J, Elwood P et al. (2011) The role of reducing intakes of saturated fat in the prevention of cardiovascular disease: where does the evidence stand in 2010? Am J Clin Nutr 93, 684-688.

60. Vafeiadou K, Weech M, Altowaijri H et al. (2015) Replacement of saturated with unsaturated fats had no impact on vascular function but beneficial effects on lipid biomarkers, E-selectin, and blood pressure: results from the randomized, controlled Dietary Intervention and VAScular function (DIVAS) study. Am J Clin Nutr 102, 40-48.

61. Nestel PJ, Chronopulos A \& Cehun M (2005) Dairy fat in cheese raises LDL cholesterol less than that in butter in mildly hypercholesterolaemic subjects. Eur J Clin Nutr 59, 1059-1063.

62. Tricon S, Burdge GC, Jones EL et al. (2006) Effects of dairy products naturally enriched with cis-9,trans- 11 conjugated linoleic acid on the blood lipid profile in healthy middleaged men. Am J Clin Nutr 83, 744-753. 
63. Drehmer M, Pereira MA, Schmidt MI et al. (2016) Total and full-fat, but not low-fat, dairy product intakes are inversely associated with metabolic syndrome in adults. J Nutr 146, 81-89.

64. O'Sullivan TA, Bremner AP, Mori TA et al. (2016) Regular fat and reduced fat dairy products show similar associations with markers of adolescent cardiometabolic health. Nutrients $\mathbf{8}, \mathrm{E} 22$.

65. Vaskonen T (2003) Dietary minerals and modification of cardiovascular risk factors. J Nutr Biochem 14, 492-506.

66. Buchowski MS, Aslam M, Dosset C et al. (2009) Effect of dairy and nondairy calcium on fecal fat excretion in lactose digester and maldigester obese adults. Int J Obes (Lond) $\mathbf{3 4}$, $127-135$.

67. Christensen R, Lorenzen JK, Svith CR et al. (2009) Effect of calcium from dairy and dietary supplements on faecal fat excretion: a meta-analysis of randomized controlled trials. Obes Rev 10, 475-486.

68. Beal T, Massiot E, Arsenault JE et al. (2017) Global trends in dietary micronutrient supplies and estimated prevalence of inadequate intakes. PLoS One 12, e0175554.
69. Zanchett D, Bosco SMD, Arend AJ et al. (2015) Relação entre excesso de peso e consumo de cálcio em crianças e adolescentes. Rev Baiana Saude Publica 39, 64-73.

70. Assumpção D, Dias MRMG, Barros MBA et al. (2016) Calcium intake by adolescents: a population-based health survey. J Pediatr (Rio J) 92, 251-259.

71. Wang Lang L, Manson JE \& Sesso HD (2012) Calcium intake and risk of cardiovascular disease. A review of prospective studies and randomized clinical trials. Am J Cardiovasc Drugs 12, 105-116.

72. Levy RB, Claro RM, Mondini L et al. (2012) Regional and socioeconomic distribution of household food availability in Brazil, in 2008-2009. Rev Saude Publica 46, 15-28.

73. Sociedade Brasileira de Pediatria (2012) Manual de Orientação para a Alimentação do Lactente, do Pré-escolar, do Escolar, do Adolescente e na Escola/Sociedade Brasileira de Pediatria. Departamento de Nutrologia, $3^{\text {a }}$ ed. Rio de Janeiro: SBP.

74. Levy-Costa RB, Sichieri R, Pontes NS et al. (2005) Disponibilidade domiciliar de alimentos no Brasil: distribuição e evolução (1974-2003). Rev Saude Publica 39, 530-540. 